\title{
THE OPTIMIZATION OF CHARACTER BUILDING OF STUDENTS THROUGH THE IMPLEMENTATION OF QUANTUM TEACHING
}

\author{
Abd. Ghofur* \\ STKIP PGRI Lamongan \\ Doctoral Candidate Instructional Technology at the State University of Malang
}

\begin{abstract}
Various negative character performed by students last few years is certainly a lot of attention. Students are supposed to be busy with learning activities and produce innovative work turned out to behave less commendable. For example, fighting between students, always late to class, coloring the school and public areas, and other negative characters. Some negative character is not separated from the educational process are realized in the study conducted by teachers at school. Students also of humans that has sides that must be understood and humanist has diverse potential to be channeled. A person's character is obtained from the knowledge through the senses that he get continuously and processed in the mind. Inside the mind there is a whole program that is formed from the experience of one's life. The program then form a belief system that can eventually form a mindset that can affect behavior. If the program is embedded in accordance with the principles of universal truth, his behavior goes in harmony with natural law. As a result, the behavior brings peace and happiness. Conversely, if the program is not in accordance with the principles of universal law, then the behavior is brought damage and produce suffering. Students learn in school is considered as the burden of life and the imposition of the will of their parents and teachers. Often occurs gap between the desire of students to teachers' concerns, so that what is expected of students by teachers can't meet the goal. As a result, teachers often use anger and even violence to force the students understand the lesson being taught. Negative behaviors performed by the teacher is not directly recorded in the minds of students and manifested in the form of daily actions. Quantum Teaching invites teachers to enter the world of students and teachers bring into the world. Teacher puts himself in line with the students and make learning fun. So that learning is no longer forced, but purely coming from each student. Additionally, Quantum Teaching also apply 8 (eight) key advantage into daily lesson plans, namely: 1) integrity, 2) the failure of early success, 3) speak with good intentions, 4) live in today, 5) Commitment, 6) responsibility, 7) open and flexible attitude, 8) balance. Hopefully, the positive character of the students can be formed through the fun of learning design.
\end{abstract}

Keywords: Character Building, Fun, Quantum Teaching

\section{A. INTRODUCTION}

Every human being is born in a clean condition and the sacred, the surrounding environment and conditions that make up the human characteristics. Many people who complain about the behavior of children in this age that is far from under control. Even many who discriminate against children in the past why his behavior is better than at present. What exactly is the difference between the education of children in the past with this era of educational models that lead to differences in the character?.

According Fahruddin (2008), the failure of education to inculcate human values seen by placing Indonesia is among the corrupt countries, many special schools for investors, the rich and the poor do not get it, the school seems to be a trigger for their marginalization who can not get an education. It is getting close humanist values in education. Still widespread culture clash, high crime rates, corruption, collusion and nepotism of educated people who assure us that there is something wrong in our education.

The main goal is to help the student educators to develop themselves by helping each individual to know themselves as humans are helping to realize all the potential that exists within. This is in line with UU No. 20/2003 on the National Education System, Article 3, which reads: National Education 
serves to develop the ability and character development and civilization of dignity in the context of the intellectual life of the nation, aimed at developing the potential for students to become a man of faith and fear of God Almighty, noble, healthy, knowledgeable, skilled, creative, independent, became a citizen of a democratic and responsible.

The government in this case the Ministry of Education and Culture in recent years emphasized the formation of character in each subject they teach. This is starting to set out on a lesson plan (RPP) in the respective subjects. But unfortunately the idea of character education was limited to the writing on the lesson plan, but minimal practice. There are still many visible teachers teach with violence, providing redundant tasks and teaching styles are still monotonous. The impact is that the students begin to saturate go to school, because learning in school is considered as a burden and contains material pressure. Finally they opted out in the street, playing games in the rental, and various other activities with the main reason to avoid lessons and meet their teachers who are considered to be a burden.

Character values held by students is closely linked to their current learning activities of the school. The model and the way teachers treat students in the learning process will have an impact on admissions to lessons delivered. Quite often students who are willing to wait for the arrival of their teacher during the lesson begins, because the teacher can understand how to treat the student in the learning process. Not infrequently, students are reluctant to follow the lessons because teachers saturate and less favored students.

Quantum Teaching put the sides of humanity students in the learning process. Quantum Teaching has the main principles, namely: the world bring them into our world, and deliver our world into their world. The main intent of this principle is the first step that must be done in teaching that is trying to enter the world experienced by students. How that is done by a teacher is to teach an event, thought or feeling obtained from the home life, social, musical, artistic, recreational or academic them. After the connection is established, it can bring them into our world and give them an understanding of the content of the world. "Our World" was extended to include not only the students, but also teachers. Through understanding the broader and more in-depth mastery of this, students can take what they learned into their world and apply it to new situations.

De Porter (2000) states that Quantum Teaching someone to show to be a good teacher. Quantum Teaching shows new ways that facilitate learning by guiding elements of art and the achievements of targeted, whatever the subjects taught. Third Quantum Teaching teachers to use, they will be able to combine privileges lessons learned to the planning form that will jump-start student achievement.

Planting effective character education is through the model observed by the students, especially the behavior of learners observe every day, either directly or through the media. For example, television, behavior when the teacher says, and so forth. Whatever is seen and felt by the children will be recorded clearly in real activity they do. Students also need to be understood people who wish to accept and appreciate something. So that the role of teachers in the world entered and asked her students to a world that is desired by the teacher indirectly will direct the formation of the character of the students become better.

\section{B. QUANTUM CONCEPT}

TEACHING

Quantum Teaching is derived from two words, namely "Quantum" which means the interaction that converts energy into light, and "teaching" that has a sense of teaching. Thus, Quantum Teaching orchestration various interactions that exist in the moment and learn. These interactions include elements of effective learning that can affect student success.

Nata (2003) cites his opinion Quantum Teaching DePorter that body of knowledge and methodology used in the design, presentation and facilitation Super Camp. Quantum Teaching created based on educational theories such as Accelerated Learning (Lozanov), Multiple Intelligence (Gardner), Neuro-Linguistic Programming (Ginder \& Bandler), experiential learning (Hahn), Socratic Incuiry, cooperative learning (Johnson \& Johnson), and Element of Effective 
Instruction (Hunter). Quantum Teaching weave the most excellent of the best into multisensory package, multiple intelligence, and is compatible with the brain, which in turn would unleash a teacher's ability to inspire, and the ability of students to excel.

Quantum Teaching pioneered by Bobbi DePorter and Mark Reardon and began to be developed in the United States around 1999. Quantum Teaching begins at Super Camp, an acceleration of Quantum Learning programs offered by the Learning Forum. According DePorter (2000) Super Camp is a program of stay for twelve days, where students gain tips that help students in the notes, memorizing, reading, writing, creativity, communication and relationships with others. The results achieved in Super Camp: 68\% increase motivation, $73 \%$ increase in value, $81 \%$ increase confidence, improve self-esteem $84 \%$, and $98 \%$ continue to use the skills.

Quantum Teaching is a process of learning by providing background and strategies to enhance the learning process and make the process more enjoyable. This method gives a teaching style that empowers students to achieve more than that considered possible. This learning model also helps teachers broaden the skills and motivation of students, so teachers will gain greater satisfaction from his efforts.

According DePorter (2000), in Quantum Teaching, there are three things that must be understood, namely Quantum, accelerated learning, and facilitation. Quantum means the interactions that convert energy into light. So Quantum Teaching is an attempt teachers orchestrate the various interactions that are in and around the moment of learning, so that students' natural abilities and talents into light. Interactions include elements for effective learning that affect student success, as well as the ability to change students' natural talents into light that benefit themselves and others.

Accelerated learning means getting rid of the barriers that hinder the natural learning process by deliberately using music, coloring the surrounding environment, prepare appropriate teaching materials, and active involvement. Facilitation means to simplify everything. Facilitation in this context refers to the implementation of the strategy in removing barriers to learning, returns to the learning process easy and natural state. This facilitation also includes the provision of assistive devices that facilitate student learning, (DePorter, 2000).

Quantum Teaching as a private teacher puts a pleasant and acceptable student behavior. So that whatever was done by the teacher into something very awaited by the students to do. Once the student teacher is able to control the world, the process of formation of the student's character would be very easy to do. Therefore, students do every directions given by the teacher with enthusiasm.

In addition, there are five principles that are used in the Quantum Teaching, namely: (1) all talk, (2) all purpose, (3) experience before naming, (4) admit every effort, (5) if it is worth examining, then it is worth celebrated.

1. All talk, everything speaks principle implies that "everything in the classroom talking" to send a message about learning.

2. All purpose, principles all aimed means that all the efforts made in changing classroom teachers have a purpose, namely that students can learn optimally to achieve high performance.

3. Experience before naming, most good learning occurs when students have experienced information before they acquire a name for the things they learned. Experience creating mental questions, such as: What ?, Why ?, How ?. Clearly the experience to build the curiosity of students, creating questions in their minds, make them curious. In such conditions, then the teacher gives the name: explain the subject matter. So, before presenting the subject matter, the teacher should first provide an opportunity for students to experience or practice itself.

4. Admit every effort, recognition of student efforts are intended to enable them to achieve better results. It should be emphasized here, that in Quantum Teaching is not known the term "fail". There is only the results and feedback. Each result is the achievement, whether appropriate or not, and each will be a feedback for the achievement of results exactly as intended. Therefore, all efforts should be rewarded or recognized student. 
5. If it is worth examining, then it is worth celebrated. Celebration gives feedback on progress and increase positive emotions associated with learning. In the learning process, teachers and students need frequent celebrate learning, and connecting learning, with celebrations. Form of celebration, for example: applause, three times hurray, flick of a finger, shock, and others.

There are several advantages and disadvantages when applied quantum teaching in the learning process. Excess Quantum Teaching is a) always centered on what makes sense for students, b) grow and generate the enthusiasm of students, c) the cooperation, d) to offer ideas and processes in the form of delicious brilliant student understood, e) create the behavior and attitudes confidence in yourself, f) learning was fun, g) Peace of psychology, h) Motivation from within, i) the existence of freedom of expression, and $\mathrm{j}$ ) foster idealism, passion and love taught by the teacher. While the lack of Quantum Teaching is: a) requires a thorough preparation for teachers and a supportive environment, b) requires adequate facilities, c) this model is mostly done abroad that are less adapted to life in Indonesia, and d) are less able to control students.

\section{CHARACTER BUILDING CONCEPT}

Characters are often heard and spoken, especially the last few years, but what exactly is the character?. According to Singh and Aghwan (2000), in a language the character is character or habits. Meanwhile, according to psychologists, the character is a system of beliefs and practices that direct the actions of an individual. Therefore, if the knowledge of a person's character can be known, it can be seen also how these individuals will be for certain conditions.

According to Byrne (2007) that the most important element in the formation of character is the mind. For in mind there is a whole program that is formed from the experience of one's life is a pioneer everything. The program then form a belief system that can eventually form a mindset that can affect behavior. If the program is embedded in accordance with the principles of universal truth, his behavior goes in harmony with natural law. As a result, the behavior brings peace and happiness. Conversely, if the program is not in accordance with the principles of universal law, then the behavior is brought damage and produce suffering.

Murphy (2002) says that in man there is a mind that has different characteristics. To distinguish these characteristics, then the term is called the conscious mind or objective mind and subconscious mind or subjective mind. In connection with this, Gunawan (2005) explains that the conscious mind that is physically located in the cortex of the brain is logical and analysis to have the effect of $12 \%$ of the brain's ability. While the subconscious mind is physically located in the medulla oblongata that had formed while still in the womb. Therefore, when a baby is born crying, the baby will calm down in the arms of his mother because she already felt familiar with the mother's heartbeat. The subconscious mind is neutral and suggestive.

Conscious and unconscious mind continues to interact. The subconscious mind will run what had been suggested to him through a belief system that was born from the logical conclusion of the conscious mind to the outer object observed. Because, the subconscious mind will continue to follow the impression of the conscious mind, the conscious mind is likened to the master while the subconscious mind likened crew ready to run the command, regardless the order was right or wrong. Here, the conscious mind can act as a guard to protect the subconscious mind of the influence of external objects, (Gunawan and Setyono, 2006).

According Setyono (2006), naturally, from birth until the age of three years, or perhaps up to about five years, the ability to reason a child has not grown so your subconscious mind (subconscious mind) is still open and accepting any information and stimulus put into it without any selection, ranging from parents and family environment. From these, the initial formation of the character of the foundation is already built. The foundation is a certain confidence and self-concept. If as a child both parents were 
always fighting then divorced, then the child can take their own conclusions that the marriage was suffering. However, if both parents have always shown respect to the familiar form of communication that the children will conclude the wedding turned out beautifully. All of this will have an impact when it was growing up.

Furthermore, all the life experiences that come from the environment relatives, schools, television, Internet, books, magazines, and various other sources add to the knowledge that will lead someone has a greater ability to be able to analyze and make sense of external objects. Starting from here, the role of the conscious mind became increasingly dominant. Over time, the filtering of the information coming through the conscious mind becomes more stringent so that not just the information coming through the senses can be easily and immediately accepted by the subconscious mind.

Information and knowledge gained in school through the learning process also indirectly affect the formation of a person's character. The most simple and easy to understand once practiced by the students is how teachers teach, how teachers act and say. What is being done by the teachers and the people around him greatly impact on the behavior of children. When teachers teach with heart, soft-spoken and adjust to the conditions of their students will follow the softness of the attitude of the students, and vice versa. This means that every child has the characteristics of humanity, if he treated with touching humanity, then the child will quickly respond.

\section{IMPLEMENTATION OF QUANTUM TEACHING IN THE CHARACTER BUILDING}

Every child between one and the other has definitely different character. Many of the reasons that make a character inherent in children, but education is the benchmark in driving character of children towards better. One is the way and the behavior of teachers treat their students in the learning process.

According A'la (2010), Quantum Teaching is a program that allows educators to understand the differences in learning styles of the students in the classroom. The goal is to teach educators how people learn and why students act and react to things as they happen during this time. Quantum Teaching shows teachers how to fabricate their students' success by noting "anything" in the classroom related to the environment, the design of the curriculum and how to present it. Quantum Teaching offers new ideas about how to create an environment that is much better and promising for students and support them in the learning process in order to avoid imbalance.

The occurrence of negative behavior of the student begins the student indifference to the lessons they follow. They prefer ditching than following subjects deemed students saturate and bind their freedom. Expression of students who are not channeled in school makes them vent their ability elsewhere. No matter if the place that made the students' ability to express precisely, if the place one would be dangerous and affect psychology students. It is often seen is the students singing in the street when school hours, or scribble on the walls of public areas.

Committed violent behavior in school also affects the formation of the character of students. For example, hitting students while not doing a task, or scold students who are late to class, or even a curse teachers because students do not understand the lessons that have been taught. What was done by the teacher indirectly teaches the child to imitate the behavior performed by the teacher. As a result many brawl between students, swearing into the habit of students, and other negative characters.

Some of the constraints experienced by the teachers is about the main reason why they do not listen to the student or the teacher liked. The reason is the teachers are not able to comprehend and understand what is desired so impressed between students and teachers are chasm that separates the two. So that the learning process was limited to the ceremony without making the students are able to express the potential that exists within him, (A'la, 2010)

White (2004) also agrees that often occurs misconceptions between teachers and students in the learning process. Teachers expect on a goal they want to achieve, but 
ignore the condition of students while learning. Often the teacher also knows what it wants to be produced in a learning process, but in the end the results are to be missed. In disposition, every child is born with a variety of intelligence and different learning styles. Teachers always assume that all students are always ready to follow the lessons. Though often seen in the classroom there are students who are sleepy, dreamy, playing themselves, some are paying close attention, writing every speech teacher, and a variety of other actions. It shows that every student has a different motivation in learning, which will certainly affect the learning process.

Tung Desum Waringin in a nationally televised event says a study from Harvard University. He explained that many people assume that if a successful person will be happy. The results of the Harvard University turned out the opposite, that will happily deliver someone to be successful. The survey results were presented by Tung Desum Waringin also proves that people are in a state of happy outcome will work better and satisfying. Happy usher somebody to do something no-load and full as motivation. The more children are burdened with a load of lessons and tasks, then the child will be frustrated by the limitations of his ability. The result will affect the student's psychological condition

Quantum Teaching learning model lies in the ability of the teacher how to bridge the gap between the world's students with teachers. According A'la (2010) instructions that can be done to implement Quantum Teaching teachers in the learning process, including:

1. The teacher shall give the example of so worthy of being a role model for students, speak the truth, so a good listener and always happy (smile)

2. Teachers should be able to make learning fun, for learning will be more effective if in pleasant conditions. Fun here means the rise of interest, full involvement, and the creation of meaning, understanding (mastery over the material being studied), and the value of joy on students.

3. The learning environment that is safe, comfortable and can bring excitement, example: formation arrangements of tables and chairs, and spatial classes are designed to make students feel at home and enthusiastic to learn.

4. Teachers must understand that the feelings and attitudes of the students will be involved and a strong influence on the learning process. Things that can be done is to provide stress relief activities such as singing together, and other games.

5. Playing classical music when learning takes place, but occasionally played instrumental music and can be interspersed with other types of music for fun and learning pauses.

6. The attitude of teachers to students:

a. Provide an explanation of the benefits and purposes subject matter to students

b. Treating students as equal human beings

c. Always appreciate every effort and celebrate the work of students

d. Provide a stimulus that encourages enthusiastic students

e. Student support $100 \%$ and invites all members of the class to participate in mutual support

f. Giving students the opportunity to observe and record the observed data, answer questions and questioning answers, explaining while providing a number of arguments and reasoning.

7. Applying 8 (eight) key advantage into daily lesson plans, namely: integrity, early failure of success, Talk with good intentions, Living in the moment, Commitment, Responsibility, an open and flexible attitude, balance.

A'la (2010) also explains that there are several characteristics that teachers have to communicate if you want to apply Quantum Teaching in learning, namely:

1. Enthusiastic showing passion for life

2. Authoritative: moving people 
3. Positive: Seeing opportunity in every moment

4. Supple: Easy relationships with diverse students

5. Humorous: Be open to receiving an error

6. Flexible: Found more than one to achieve results

7. Accept: Looking behind the action and outward appearance to find the core values

8. Fluency: Communicating with clear, concise and honest

9. Sincere: Having a positive intention and motivation

10. Spontaneous: Can the rhythm and keep the results

11. Interesting and interested: Linking any information with the student life experience and care about students.

12. Assume students "capable": Believe in student success

13. Establish and maintain high expectations: Making quality guidelines and quality of work relationships that spur each student to do my best.

\section{E. CONCLUSION}

Education is an activity that is meaningful to help someone as an individual, develop skills and use them. Education is also the key to the realization of the community and a better world. Children will behave as education that he experienced when learning takes place, both within the family, school and community. To shape the character of a child is in need of a process, time and some components that influence it. Some character development experienced by the child is in the family, school and community. To realize the character of a child there should be a balance of these three components.

Quantum Teaching enacted in an effort to accommodate every student's potential. In addition, Quantum Teaching puts the teacher in parallel with the students, so that sodium absorption ratio is no gap between the two. Teachers and students can build a harmonious relationship and delight in achieving learning goals. According DePorter (2002), Quantum Teaching is a teacher attempts to orchestrate the various interactions in the learning process into light that jump-start student achievement, by removing barriers to learning through the use of appropriate methods and tools, so that students can learn easily and naturally.

Character and the way teachers teach a determinant of how students behave on everything that he obtained. For example, teachers angry and hit students because they were working on, or students do not understand the above explanation of the lessons that have been submitted by the teacher. The teacher's behavior will certainly psychological impact for the student's behavior. It may be that the students prefer to skip school for fear of being scolded by his teacher, or student prefers scribble school walls because of his talents never get a response from the teacher.

Each child will act as what he saw, he heard and he feels. When the boy said dirty and nasty, mean he heard around him say it. If the children behave rudely mean he learned that from what he felt. This means that each child will imitate any information both verbal and non-verbal of what he experienced.

Therefore, Quantum Learning Model of teaching can be done if a teacher to behave positively during the learning process. Among the required behavior is enthusiastic, authoritative, positive thinking, sociable, be roomy, providing many solutions, communicate precise, positive intention, the rhythm and keep the results, believe the ability of students, and optimistic.

\section{F. REFERENCES}

A'la, M. 2010. Quantum Teaching. Jogjakarta: Diva Press.

Byrne, R. 2007. The Secret. Jakarta: PT Gramedia

De Porter, B. dan Hernacki, M. 2002. Quantum Learning. Translated by Alwiyah Adurrahman. Bandung: Kaifa PT Mizan Pustaka.

De Porter, B. Reardon, M. Singer, S. dan Nourie. 2000. Quantum

Teaching. Editor, Hernacki, Mike. Translated by Ary Nilandari. Bandung: Kaifa PT Mizan Pustaka 
Fahruddin, M., M. 2008. Konsep Humanis dalam Perspektif Al Qur'an. Unpublished thesis. Yogyakarta: PPS UIN Sunan Kalijaga.

Gunawan, A. W. 2005. Hypnosis - The Art of Subconscious Communication. Jakarta: PT Gramedia Pustaka Utama

Gunawan, A. W. Setyono, A. 2006. Manage Your Mind for Success. Jakarta: PT. Gramedia Pustaka Utama.

Murphy, Joseph D.R.S. 2002. Rahasia Kekuatan Pikiran Bawah Sadar. Jakarta: SPEKTRUM
Nata, A. 2003. Manajemen Mengatasi kelemahan Pendidikan Islam di Indonesia. Jakarta: Kencana.

Setyono, A. 2006. Hypnoparenting: Menjadi Orangtua Efektif dengan Hipnosis. Jakarta: PT. Gramedia Pustaka Utama.

Singh, N.K. Agwan, A.R. 2000.

Encyclopaedia of the Holy Qur'ân. New Delhi: Balaji Offset

White, A. 2004. Impact of Student Motivation on Teaching and Learning. The Agriculture Educational Magazine. Vol. 76 (4): (pp) 14-16. 